\title{
Peripheral blood cells among community residents living near nuclear power plants
}

\author{
Yuan-Teh Lee ${ }^{\mathrm{a}, *}$, Fung C. Sung ${ }^{\mathrm{b}}$, Ruey S. Lin ${ }^{\mathrm{c}}$, Hsiu-Ching Hsu ${ }^{\mathrm{a}}$, \\ Kuo-Liong Chien ${ }^{\mathrm{a}}$, Chi-Yu Yang ${ }^{\mathrm{a}}$, Wen Jone Chen ${ }^{\mathrm{a}}$ \\ ${ }^{a}$ Department of Internal Medicine, National Taiwan University College of Medicine, No. 7 Chungshan South Road, \\ Taipei 10020, Taiwan, ROC \\ ${ }^{\mathrm{b}}$ Institute of Environmental Health, National Taiwan University College of Public Health, Taipei, Taiwan, ROC \\ ${ }^{\mathrm{c}}$ Institute of Epidemiology, National Taiwan University College of Public Health, Taipei, Taiwan, ROC
}

Accepted 16 March 2001

\begin{abstract}
Information about hematopoieses as a result of exposure to very low levels of radiation is scarce. To investigate the human hematopoietic effect of very low level radiation exposure, measurements of peripheral blood components were performed among 3602 men and women, aged 35 and above, living in a community near two nuclear power installations in Chinshan, Taiwan. The radiation level that each individual was exposed to was represented by a surrogate level, ' $1 / D_{1 i}^{2}+1 / D_{2 i}^{2}$ ', a transformed distance from each individual's residence to the two power plants $D_{1}$ and $\mathrm{D}_{2}$. In addition to comparing average hematology measurements, multiple regression analyses were done to include age, gender, smoking, drinking status and the surrogate radiation exposure level as independent variables. Univariate and bivariate analyses showed that the hematology measurements had significant associations with age, gender, smoking or drinking. The multiple regression analyses revealed that significant positive associations with ' $1 / D_{1 i}^{2}+1 / D_{2 i}^{2}$ ' were found for hemoglobin, hematocrit, platelet, white blood cell and red blood cell. The platelet count might increase for $208.7 \times 10^{3} / \mu$ l if the exposure from the nuclear plants increased by one exposure unit. This type of association implies that those who lived closer to the nuclear power installation had a higher blood cell count; we suspect that this could be a type of radiation hormesis. (c) 2001 Elsevier Science B.V. All rights reserved.
\end{abstract}

Keywords: Blood cell counts; Nuclear power; Radiation hormesis; Smoking

* Corresponding author. Tel.: + 886-2-2356-2000; fax: +886-2-2321-7522.

E-mail address: ytlee@ha.mc.ntu.edu.tw (Y. Lee). 


\section{Introduction}

Since the discovery of radium and X-ray, a large number of studies on radiation health effects have been reported in the medical literature (Shapiro, 1990; MacMahon, 1989; Mossman, 1998; Bond et al., 1996). There are concerns about the complex nature of radiation exposure, including that from nuclear power plants (Drottz-Sjöberg and Persson, 1993; Drottz-Sjöberg and Sjöberg, 1990; Hendee, 1990). It is a common perception that low dose radiation exposure may also lead to various health effects including leukemia, multiple myeloma, and other cancers. Leukemia has been mainly studied among the serious etiologic sequelae of low-level radiation exposure (Shapiro, 1990). Few of these studies have concluded that a convincing causal association with nuclear power exposure or other types of low-level radiation exposure exists (Little et al., 1995; Sorahan and Roberts, 1993; Boice and Lubin, 1997). The radiation exposure limits based primarily on extrapolations of dose-response from high dose exposure have thus been challenged, and a stimulatory effect (hormesis) of low-dose exposure has been hypothesized (Liu et al., 1987; Loken and Feinendegen, 1993; Webster, 1993; van Wyngarden and Pauwels, 1995; Bond et al., 1996).

Research on hematologic cell counts have also been limited to that of moderate doses of total body irradiation which induce in mice and rats, a detectable decrease in the number of circulating erythrocytes, platelets, granulocytes, lymphocytes, etc. In animal studies as well as a few human observations in clinical and other settings, data on the perturbation of hematopoieses due to low level radiation exposure have been reported (Seed and Meyers, 1993; Tanke et al., 1986). Changes in erythropoietic activity as a consequence of low dose radiation treatment for cancer patients have been detected (Tanke et al., 1986). Information remains scarce about hematopoietic effects on individuals exposed to very low levels of radiation, such as living in close proximity to nuclear power installations.

Here, we were specifically interested in the effect on blood cell counts related to the distance between the nuclear power plant and individual's residence. Radiation hormesis was addressed. We also examine the gender difference and the effects of smoking and drinking.

\section{Methods}

The study was conducted by the Department of Internal Medicine, National Taiwan University College of Medicine, as part of a Chin-shan Community Cardiovascular Cohort Study in a suburb of Taipei, Taiwan. A clinic was set up in the community by the study team consisting of 20 medical students, two assistant nurses, 10 cardiologists and local practitioners. Officers of the local health center and 14 community leaders who were familiar with all families in the community, assisted the study team by recruiting participants. This project was designed to identify and recruit men and women aged 35 and who resided near two nuclear power plants. One plant is equipped with two $636 \mathrm{MW}$ boiling water reactors (BWR) and the other equipped with two $985 \mathrm{MW}$ BWR. Surrounding environmental samples have been collected to monitor for violation of radiation exposure. Evidence showed radiation level decreased as distance increased using limited environmental samples for monitoring, but no violation has been cited.

Overall, 4349 non-institutional individuals were identified as potential participants in the cardiovascular disease study. Among them, 747 (17.2\%) were non-respondents, which included 95 refusals and 652 individuals not available for interview contacts and physical exams. Among the 3602 participants, 36 persons were excluded from data analyses regarding blood cells because of incomplete data. The clinical examination for this part of the study consisted of an interview, physical examinations and an electrocardiogram (12-lead resting). With participants' consent, fasting blood specimens were requested from each participant for measurement of lipids, hepatic, renal and other biochemical components.

The blood specimens were also used for hemoglobin $(\mathrm{Hb})$, hematocrit (HCT), red blood cell counts (RBC), mean corpuscular volume (MCV), mean corpuscular hemoglobin $(\mathrm{MCH})$, mean cor- 
puscular hemoglobin concentration (MCHC), white blood cells (WBC) and platelets (PLT), as determined by an F-800 Hematology Analyzer (Sysmex). Samples preserved in ice were transferred to the medical center and analyzed within $8 \mathrm{~h}$. These peripheral blood cell counts were studied in the connection with hematopoietic effects of the very low levels of radiation of the nuclear power installations. Since the background radiation doses were not provided by the company, surrogate exposure levels were used. Each individual's results were associated with a transformed distance from each individual's residence to the location of the two nuclear power plants, $D_{1}$ and $D_{2}$ by the following formula $1 / D_{1 i}^{2}+1 / D_{2 i}^{2}$, where $D_{1 i}=$ the distance between the individual's residence and the nuclear power plant number 1 in $\mathrm{km}$, and $D_{2 i}=$ the distance between the same individual residence and the nuclear power plant number 2 in $\mathrm{km}$. The distances $D_{1}$ (mean $=3.4$ $\mathrm{km}$, S.D. $=1.6 \mathrm{~km})$ and $D_{2}($ mean $=4.3 \mathrm{~km}$, S.D. $=1.7 \mathrm{~km}$ ) were measured based on municipal planning maps constructed by the civil engineers of the local authority (Fig. 1). Greater values for $D_{i}$ indicates longer distance and lower exposure, or smaller value in $1 / D_{i}^{2}$.

The initial descriptive analyses were performed using SASPC to observe average peripheral blood cells counts by quartiles of exposure and identify possible confounding variables such as gender, age and smoking. Nordenberg et al. (1990) re- ported that the hemoglobin level is significantly higher for smokers than non-smokers. Relationships between the hematology measurements and radiation exposure (the transformed distance) were calculated using Pearson correlation coefficient. The actual effects of radiation on the hematology measurements were also calculated using an average (by quartile) of the transformed distance. The statistical significance of the mean difference of the average hematologic values between quartiles of $\left(1 / D_{1 i}^{2}+1 / D_{2 i}^{2}\right),<25 \%$, $25-49.9 \%, 50-74.9 \%$ and $\geq 75 \%$, and was determined using analysis of variance. This report presents results on smoking status as hematology measurements were different between smokers and non-smokers. For example, the average hemoglobin level in smokers was higher than that in non-smokers. Only $3.1 \%$ of females were smokers and the relationship of interest should not be confounded by the smoking status for females.

Multiple regressions were then performed to obtain a correlation between blood cells counts and age, sex $($ male $=1$, female $=0)$, daily number of cigarettes smoked, drinking and the surrogate radiation exposure.

\section{Results}

Men were on average two years older than women. A significantly higher proportion of men

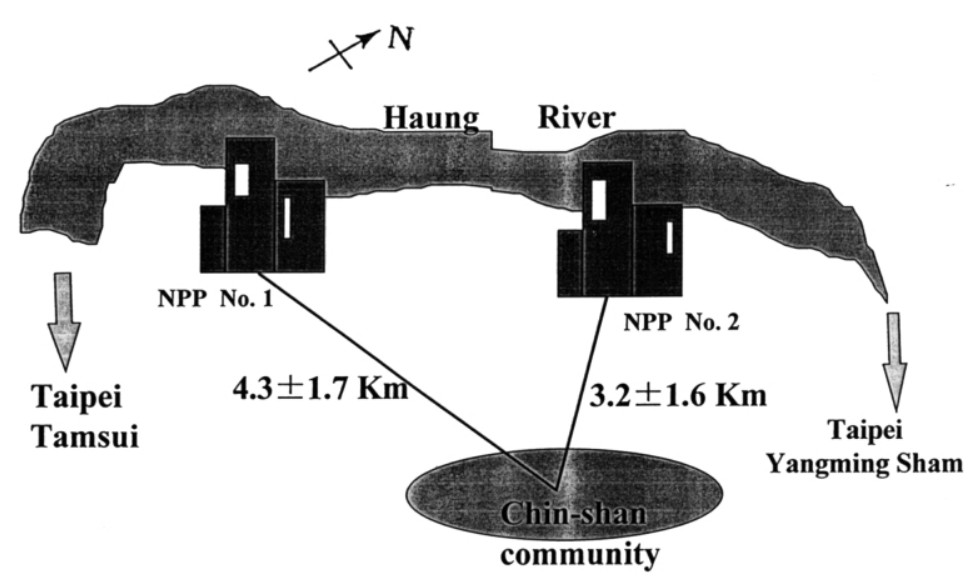

Fig. 1. Locations of the nuclear power plants and the Chin-shan community. 
Table 1

Means (S.D.) of hematology measurements by smoking status and gender

\begin{tabular}{|c|c|c|c|c|c|c|}
\hline \multirow[t]{2}{*}{ Measurement } & \multicolumn{3}{|l|}{ Males } & \multicolumn{3}{|l|}{ Females } \\
\hline & $\begin{array}{l}\text { Non-smoker } \\
n=649\end{array}$ & $\begin{array}{l}\text { Smoker } \\
n=1054\end{array}$ & $P$ & $\begin{array}{l}\text { Non-smoker } \\
n=1813\end{array}$ & $\begin{array}{l}\text { Smoker } \\
n=86\end{array}$ & $P$ \\
\hline $\mathrm{Hb}^{\mathrm{a}}(\mathrm{g} / \mathrm{dl})$ & $14.6(1.6)$ & $14.9(1.8)$ & 0.0008 & $13.1(1.4)$ & $13.3(1.5)$ & 0.3136 \\
\hline $\operatorname{HCT}^{\mathrm{b}}(\%)$ & $45.1(5.1)$ & $45.7(5.4)$ & 0.0296 & $41.0(4.9)$ & $41.5(4.8)$ & 0.4002 \\
\hline $\mathrm{MCV}^{\mathrm{c}}$ (fl) & $91.8(7.3)$ & $94.0(8.0)$ & 0.0001 & 91.7 (7.4) & 91.7 (8.6) & 0.9845 \\
\hline $\mathrm{MCH}^{\mathrm{d}}(\mathrm{pg})$ & $29.9(4.8)$ & $30.8(4.8)$ & 0.0001 & $29.5(5.0)$ & $29.4(3.5)$ & 0.8217 \\
\hline $\operatorname{MCHC}^{\mathrm{e}}(\mathrm{g} / \mathrm{dl})$ & $32.5(3.9)$ & $32.8(4.4)$ & 0.2136 & $32.2(5.0)$ & $32.1(2.2)$ & 0.5853 \\
\hline $\operatorname{PLT}^{\mathrm{f}}\left(10^{3} / \mu \mathrm{l}\right)$ & $265.3(84.3)$ & $257.3(75.6)$ & 0.0503 & $276.0(84.9)$ & $276.0(88.5)$ & 0.9986 \\
\hline $\operatorname{WBC}^{\mathrm{g}}\left(10^{3} / \mu \mathrm{l}\right)$ & $6.3(1.6)$ & $6.7(1.8)$ & 0.0001 & $6.1(1.6)$ & $6.7(2.0)$ & 0.0027 \\
\hline $\operatorname{RBC}^{\mathrm{h}}\left(10^{6} / \mu \mathrm{l}\right)$ & $4.9(0.6)$ & $4.9(0.6)$ & 0.0766 & $4.5(0.6)$ & $4.6(0.7)$ & 0.4304 \\
\hline $\begin{array}{l}{ }^{\mathrm{a}} \text { Hemoglobir } \\
\mathrm{b} \text { Hematocrit } \\
{ }^{\mathrm{c}} \text { Mean corpu } \\
{ }^{\mathrm{d}} \text { Mean corp } \\
{ }^{\mathrm{e}} \text { Mean corpu } \\
{ }^{\mathrm{f}} \text { Platelet. } \\
{ }^{\mathrm{g}} \text { White bloo } \\
{ }^{\mathrm{h}} \text { Red blood }\end{array}$ & $\begin{array}{l}\text { volume. } \\
\text { hemoglobin. } \\
\text { hemoglobin ce }\end{array}$ & ation. & & & & \\
\hline
\end{tabular}

than women were current smokers $(61.9 \%$ vs. $4.5 \%)$ and drinkers $(43.6 \%$ vs. $6.5 \%)$. Men also outnumbered women in employment $(68.3 \%$ vs. $22.1 \%)$

Mean levels of each hematological measurement were compared by gender, by age, and by smoking status. Most mean levels of hematological measurements were significantly higher for men than for women (data not shown) except PLT, which was higher for women $\left(276 \times 10^{3} / \mu 1\right)$ than for men $\left(260 \times 10^{3} / \mu \mathrm{l}\right)$. Average values of $\mathrm{Hb}$, HCT, PLT and RBC decreased as age increased. Measurements of MCV and MCH were positively associated with age. Table 1 shows that the mean values among men were significantly higher for smokers than for non-smokers on $\mathrm{Hb}, \mathrm{HCT}, \mathrm{MCV}$, $\mathrm{MCH}$ and WBC; however, smokers had a lower PLT mean value than non-smokers. WBC was the only item with a significantly higher mean value for female smokers, compared with non-smokers.

The Pearson correlation coefficients were calculated between each hematological measurement and the exposure by smoking status and gender (Table 2). Significant associations were identified in $\mathrm{Hb}$, and HCT for male non-smokers, in $\mathrm{Hb}, \mathrm{HCT}$, PLT, WBC and RBC for male smokers, and in HCT and PLT for female non- smokers, i.e. counts increased as distances decreased. The association in $\mathrm{MCHC}$ for females was inversely related to the exposure at a borderline significance level $(P=0.05)$. Comparisons of average values between exposure quartiles for items found to be significant from the Pearson correlation coefficients for male non-smokers and smokers, are presented in Table 3 . The trends of $\mathrm{Hb}$ and HCT were significant for male nonsmokers; the average $\mathrm{Hb}$ was $14.2 \mathrm{~g} / \mathrm{dl}$ for individuals at the lowest exposure quartile. The $\mathrm{Hb}$ value increased to $14.6 \mathrm{~g} / \mathrm{dl}$ for the second exposure quartile, and to $15.0 \mathrm{~g} / \mathrm{dl}$ for the nonsmokers with strongest exposure.

Data for results of multiple regression analyses are also given in Table 4. Levels of $\mathrm{Hb}, \mathrm{HCT}$, PLT, and RBC had a significant negative correlations with age $(P<0.001)$. Males had higher levels of $\mathrm{Hb}, \mathrm{HCT}, \mathrm{WBC}$ and RBC $(P<0.001)$, but lower PLT $(P<0.01)$ than females had. Those who smoked more had significantly higher levels of $\mathrm{Hb}, \mathrm{HCT}, \mathrm{MCV}, \mathrm{MCH}$ and $\mathrm{WBC}$, and those who drank more had significantly higher levels of $\mathrm{Hb}, \mathrm{MCV}, \mathrm{MCH}(P<0.001)$ but lower levels of WBC $(P<0.05)$.

Of interest was the observation that levels of $\mathrm{Hb}, \mathrm{HCT}, \mathrm{PLT}, \mathrm{WBC}$ and RBC had a positive 
Table 2

Pearson correlation coefficients ( $P$-values in parentheses) between hematology measurement and transformed distance $\left(1 / D_{1 i}^{2}+\right.$ $\left.1 / D_{2 i}^{2}\right)$ by gender and smoking status

\begin{tabular}{|c|c|c|c|c|}
\hline & \multicolumn{2}{|l|}{ Males } & \multicolumn{2}{|l|}{ Females } \\
\hline & $\begin{array}{l}\text { Non-smoker } \\
n=649\end{array}$ & $\begin{array}{l}\text { Smoker } \\
n=1054\end{array}$ & $\begin{array}{l}\text { Non-smoker } \\
n=1813\end{array}$ & $\begin{array}{l}\text { Smoker } \\
n=86\end{array}$ \\
\hline $\mathrm{Hb}^{\mathrm{a}}(\mathrm{g} / \mathrm{dl})$ & $0.186(0.0001)$ & $0.064(0.04)$ & $0.024(0.31)$ & $0.007(0.94)$ \\
\hline $\mathrm{HCT}^{\mathrm{b}}(\%)$ & $0.150(0.0001)$ & $0.070(0.02)$ & $0.051(0.03)$ & $0.036(0.74)$ \\
\hline $\mathrm{MCV}^{\mathrm{c}}(\mathrm{fl})$ & $0.067(0.09)$ & $-0.035(0.26)$ & $0.005(0.82)$ & $0.098(0.37)$ \\
\hline $\mathrm{MCH}^{\mathrm{d}}(\mathrm{pg})$ & $0.046(0.25)$ & $-0.038(0.22)$ & $-0.034(0.15)$ & $0.048(0.66)$ \\
\hline $\operatorname{MCHC}^{\mathrm{e}}(\mathrm{g} / \mathrm{dl})$ & $0.027(0.50)$ & $-0.010(0.76)$ & $-0.046(0.05)$ & $-0.046(0.68)$ \\
\hline $\operatorname{PLT}^{\mathrm{f}}\left(10^{3} / \mu 1\right)$ & $0.040(0.31)$ & $0.116(0.0001)$ & $0.083(0.0005)$ & $0.018(0.87)$ \\
\hline $\operatorname{WBC}^{\mathrm{g}}\left(10^{3} / \mu 1\right)$ & $0.059(0.14)$ & $0.187(0.0001)$ & $0.037(0.12)$ & $0.005(0.97)$ \\
\hline $\operatorname{RBC}^{\mathrm{h}}\left(10^{6} / \mu 1\right)$ & $0.086(0.03)$ & $0.100(0.0014)$ & $0.043(0.07)$ & $-0.042(0.70)$ \\
\hline
\end{tabular}

\footnotetext{
${ }^{\mathrm{a}}$ Hemoglobin.

${ }^{\mathrm{b}}$ Hematocrit.

${ }^{\mathrm{c}}$ Mean corpuscular volume.

${ }^{\mathrm{d}}$ Mean corpuscular hemoglobin.

${ }^{\mathrm{e}}$ Mean corpuscular hemoglobin concentration.

${ }^{\mathrm{f}}$ Platelet.

${ }^{\mathrm{g}}$ White blood cell.

${ }^{\mathrm{h}}$ Red blood cell.
}

correlations with radiation exposure level $1 / D_{1 i}^{2}$ $+1 / D_{2 i}^{2}$ in this multiple regression analysis; all were significant at the 0.001 level (Table 4). These peripheral blood component levels increased with greater exposure. For example, the PLT might increase for $208.7 \times 10^{3} / \mu 1$ if combined exposure

Table 3

Means and S.D. values (in parentheses) of hematology measurements by smoking status and the quartile distance of ' $1 / D_{1 i}^{2}+1 / D_{2 i}^{2}$ ' and significance levels of Pearson correlation for males

\begin{tabular}{|c|c|c|c|c|c|}
\hline & \multicolumn{4}{|c|}{ Exposure quartile } & \multirow[t]{2}{*}{$P^{* \mathrm{f}}$} \\
\hline & $<25 \%$ & $25.1-49.9 \%$ & $50-74.9 \%$ & $75 \%+$ & \\
\hline Non-smokers $n$ & 302 & 79 & 375 & 286 & \\
\hline $\mathrm{Hb}^{\mathrm{a}}(\mathrm{g} / \mathrm{dl})$ & $14.2(1.7)$ & $14.6(1.9)$ & $14.8(1.4)$ & $15.0(1.5)$ & 0.0001 \\
\hline $\mathrm{HCT}^{\mathrm{b}}(\%)$ & $44.0(5.4)$ & $44.2(4.9)$ & $45.5(5.3)$ & $46.0(4.4)$ & 0.0005 \\
\hline $\operatorname{PLT}^{\mathrm{c}}\left(10^{3} / \mu \mathrm{l}\right)$ & $265.8(84.3)$ & $270.2(66.3)$ & $264.4(86.8)$ & $268.4(76.2)$ & 0.8769 \\
\hline $\mathrm{WBC}^{\mathrm{d}}\left(10^{3} / \mu 1\right)$ & $6.3(1.7)$ & $6.3(1.5)$ & $6.3(1.5)$ & $6.5(1.5)$ & 0.9991 \\
\hline $\operatorname{RBC}^{\mathrm{e}}\left(10^{6} / \mu \mathrm{l}\right)$ & $4.9(0.7)$ & $4.9(0.5)$ & $5.0(0.6)$ & $5.0(0.5)$ & 0.1144 \\
\hline Smokers $n$ & 165 & 73 & 259 & 157 & \\
\hline $\mathrm{Hb}^{\mathrm{a}}(\mathrm{g} / \mathrm{dl})$ & $14.7(1.6)$ & $14.3(1.9)$ & $15.0(1.8)$ & $15.1(1.8)$ & 0.0020 \\
\hline $\operatorname{HCT}^{\mathrm{b}}(\%)$ & $45.1(5.1)$ & $45.2(8.4)$ & $46.0(5.1)$ & $46.2(4.9)$ & 0.0215 \\
\hline $\operatorname{PLT}^{\mathrm{c}}\left(10^{3} / \mu 1\right)$ & $246.4(73.0)$ & $268.7(81.2)$ & $261.0(75.7)$ & $268.0(80.6)$ & 0.0083 \\
\hline $\mathrm{WBC}^{\mathrm{d}}\left(10^{3} / \mu 1\right)$ & $6.3(1.6)$ & $6.6(2.0)$ & $6.8(1.9)$ & $7.2(2.0)$ & 0.0001 \\
\hline $\operatorname{RBC}^{\mathrm{e}}\left(10^{6} / \mu \mathrm{l}\right)$ & $4.8(0.6)$ & $4.8(0.8)$ & $4.9(0.6)$ & $5.0(0.6)$ & 0.0004 \\
\hline
\end{tabular}

\footnotetext{
${ }^{\mathrm{a}}$ Hemoglobin.

${ }^{\mathrm{b}}$ Hematocrit.

${ }^{c}$ Platelet.

${ }^{\mathrm{d}}$ White blood cell.

${ }^{\mathrm{e}}$ Red blood cell.

${ }^{\mathrm{f}} P$-value of Pearson correlation.
} 
Table 4

Parameter estimates and S.E. values (in parentheses) of multiple regression analyses: age; sex (male $=1$, female $=0$ ); daily number of cigarette smoking; daily number of drink; and radiation exposure $\left(1 / D_{1 i}^{2}+1 / D_{2 i}^{2}\right)$ related to blood cell counts and other blood characteristics for participants aged 35 and above in Chin-Shan community, Taiwan

\begin{tabular}{|c|c|c|c|c|c|c|}
\hline $\begin{array}{l}\text { Blood } \\
\text { component }\end{array}$ & Intercept & Age & Sex & Smoking & Drinking & $1 / D_{1 i}{ }^{2}+1 / D_{2 i}{ }^{2 \mathrm{i}}$ \\
\hline $\mathrm{Hb}^{\mathrm{a}}(\mathrm{g} / \mathrm{dl})$ & $\begin{array}{l}13.9 \\
(0.14)\end{array}$ & $\begin{array}{c}-0.02^{1} \\
(0.002)\end{array}$ & $\begin{array}{c}1.48^{1} \\
(0.07)\end{array}$ & $\begin{array}{c}0.23^{\mathrm{k}} \\
(0.07)\end{array}$ & $\begin{array}{c}0.28^{\mathrm{k}} \\
(0.07)\end{array}$ & $\begin{array}{c}2.86^{1} \\
(0.82)\end{array}$ \\
\hline $\mathrm{HCT}^{\mathrm{b}}(\%)$ & $\begin{array}{l}42.6 \\
(0.48)\end{array}$ & $\begin{array}{c}-0.05^{1} \\
(0.007)\end{array}$ & $\begin{array}{c}4.10^{1} \\
(0.23)\end{array}$ & $\begin{array}{c}0.55^{j} \\
(0.24)\end{array}$ & $\begin{array}{c}0.43 \\
(0.23)\end{array}$ & $\begin{array}{l}11.3^{1} \\
(2.72)\end{array}$ \\
\hline $\mathrm{MCV}^{\mathrm{c}}$ (fl) & $\begin{array}{l}87.8 \\
(0.72)\end{array}$ & $\begin{array}{c}0.07^{1} \\
(0.01)\end{array}$ & $\begin{array}{c}0.001 \\
(0.34)\end{array}$ & $\begin{array}{c}1.53^{1} \\
(0.35)\end{array}$ & $\begin{array}{c}1.34^{1} \\
(0.34)\end{array}$ & $\begin{array}{c}1.74 \\
(4.07)\end{array}$ \\
\hline $\mathrm{MCH}^{\mathrm{d}}(\mathrm{pg})$ & $\begin{array}{l}29.1 \\
(0.46)\end{array}$ & $\begin{array}{c}0.012 \\
(0.007)\end{array}$ & $\begin{array}{c}0.27 \\
(0.22)\end{array}$ & $\begin{array}{r}0.65^{\mathrm{k}} \\
(0.23)\end{array}$ & $\begin{array}{c}0.76^{1} \\
(0.22)\end{array}$ & $\begin{array}{c}-3.29 \\
(2.63)\end{array}$ \\
\hline $\operatorname{MCHC}^{\mathrm{e}}(\mathrm{g} / \mathrm{dl})$ & $\begin{array}{l}33.1 \\
(0.44)\end{array}$ & $\begin{array}{c}-0.011 \\
(0.006)\end{array}$ & $\begin{array}{c}0.29 \\
(0.21)\end{array}$ & $\begin{array}{c}0.13 \\
(0.21)\end{array}$ & $\begin{array}{c}0.34 \\
(0.21)\end{array}$ & $\begin{array}{c}-3.91 \\
(2.48)\end{array}$ \\
\hline $\operatorname{PLT}^{f}\left(10^{3} / \mu 1\right)$ & $\begin{array}{c}290.1 \\
(7.76)\end{array}$ & $\begin{array}{r}-0.62^{1} \\
(0.12)\end{array}$ & $\begin{array}{r}-11.1^{\mathrm{k}} \\
(3.65)\end{array}$ & $\begin{array}{c}-6.03 \\
(3.81)\end{array}$ & $\begin{array}{c}0.59 \\
(3.70)\end{array}$ & $\begin{array}{l}208.7^{1} \\
(44.1)\end{array}$ \\
\hline $\mathrm{WBC}^{\mathrm{g}}\left(10^{3} / \mu \mathrm{l}\right)$ & $\begin{array}{c}5.86 \\
(0.16)\end{array}$ & $\begin{array}{r}-0.004 \\
(0.002)\end{array}$ & $\begin{array}{c}0.26^{1} \\
(0.07)\end{array}$ & $\begin{array}{c}0.46^{1} \\
(0.08)\end{array}$ & $\begin{array}{r}-0.18^{j} \\
(0.08)\end{array}$ & $\begin{array}{c}4.66^{1} \\
(0.90)\end{array}$ \\
\hline $\operatorname{RBC}^{\text {h }}\left(10^{6} / \mu \mathrm{l}\right)$ & $\begin{array}{c}4.86 \\
(0.06)\end{array}$ & $\begin{array}{r}-0.009^{1} \\
(0.001)\end{array}$ & $\begin{array}{c}0.44^{1} \\
(0.03)\end{array}$ & $\begin{array}{c}-0.03 \\
(0.03)\end{array}$ & $\begin{array}{r}-0.02 \\
(0.03)\end{array}$ & $\begin{array}{c}1.16^{1} \\
(0.32)\end{array}$ \\
\hline
\end{tabular}

\footnotetext{
${ }^{\mathrm{a}}$ Hemoglobin.

${ }^{\mathrm{b}}$ Hematocrit.

${ }^{\mathrm{c}}$ Mean corpuscular volume.

${ }^{\mathrm{d}}$ Mean corpuscular hemoglobin.

${ }^{\mathrm{e}}$ Mean corpuscular hemoglobin concentration.

${ }^{\mathrm{f}}$ Platelet.

${ }^{\mathrm{g}}$ White blood cell.

${ }^{\mathrm{h}}$ Red blood cell.

${ }^{\mathrm{i}} D_{1}$ and $D_{2}$, distances between a study participant's home and nuclear power plants 1 and 2 , respectively.

$\mathrm{j} \leq 0.05$.

$\mathrm{k} \leq 0.01$

${ }^{1} \leq 0.001$.
}

from the two nuclear plants increased by one exposure unit, and HCT increased for $11.3 \%$. In other words, those living closer to the installations had higher levels of $\mathrm{Hb}, \mathrm{HCT}, \mathrm{PLT}, \mathrm{WBC}$ and $\mathrm{RBC}$.

\section{Discussion}

Data sources on the effects of low-level (and very low-level) radiation on humans may vary (Shapiro, 1990; MacMahon, 1989; Mossman 1998; Bond et al., 1996). Nuclear power installations are of particular concern (Drottz-Sjöberg and Persson, 1993; Daglish, 1988; Slovic et al., 1991). Regardless of an overwhelming number of epidemiologi- cal studies on cancer in irradiated populations, there are limited studies on the association with very low level exposure surrounding the nuclear power installations (Little et al., 1995). The cluster of childhood leukemia reported around the BNFL Sellafield nuclear reprocessing installation, Cumbria, UK, suggests paternal occupational exposures at the facilities. Further investigations failed to prove it in either case comparisons or the frequency of gene mutations in somatic cells of the workers (Cole et al., 1995; Doll et al., 1994).

It has been reported in animal studies that peripheral cell counts such as lymphocytes, granulocytes, platelets, and erythrocytes decreased as radiation increased to greater than 300 rads 
(Casarett, 1968). Severe bone marrow failure may occur in men receiving doses in excess of 1000 rads. Regulations were written to ensure appropriate controls; the release of ${ }^{85} \mathrm{Kr}$ and other radionuclides to the atmosphere has produced environmental exposures surrounding the nuclear facilities well below statutory limits, a level less than that of coal-fired plants (Davies, 1968; Fish, 1969). Investigations have not proven whether there is a health threat when it comes to such a very low order of exposure to the ionizing radiation.

However, if proliferative disorders of bone marrow occur after irradiation and there is polycythemia vera in low-level radiation exposure (Caldwell et al., 1984; Cusick, 1981), there may be an association between the exposure and molecular changes and hematopoietic counts (Little, 1993). This study for measured cellular counts among individuals living around nuclear installations, indicates that an individuals' count of blood cells are negatively associated with the distance between the individuals' residence and the nuclear reactor. Specifically, male adults whose hemoglobin and hematocrit increased significantly as the distance decreased to the plant sites (exposure measured as $1 / D_{1 i}^{2}+1 / D_{2 i}^{2}$ ). Individuals who lived near the nuclear power plants were also likely to have larger counts of platelets, white and red blood cells. These associations were stronger for smokers than for non-smokers. As for women, significant associations were only found for hematocrit and platelets in nonsmokers. The discernible negative associations identified from multiple regression analyses were impressive for $\mathrm{Hb}, \mathrm{HCT}$, PLT, WBC and RBC.

In animal studies, radiation was found to cause a reduction in the hematopoietic system of the marrow that is necessary for the production of blood cells (Boggs and Boggs, 1984). Our findings for the blood cell counts in participants were likely inverted. We also found that gender, age and smoking were factors associated with the blood cell counts, but the association remained after controlling for these factors. Although the absolute values for the differences in mean values for most of the measurements between exposure groups seemed small when data were analyzed by the quartile value of $1 / D_{1 i}^{2}+1 / D_{2 i}^{2}$. The trend was significant because the sample size was large enough to demonstrate the dose effect. For example, this trend was particularly obvious in platelet levels for male smokers; men in the higher exposure levels gained $5.9-9.1 \%\left(14.6-22.3 \times 10^{3} / \mu 1\right)$ of platelets compared with men who lived in the first quartile of $1 / D_{1 i}^{2}+1 / D_{2 i}^{2}$, the farthest from the power plants. This means that men who lived closer to the nuclear power plant had higher platelet counts.

We suspect this could be related to the controversial phenomenon of radiation hormesis that researchers had attempted to identify (Loken and Feinendegen, 1993; Webster, 1993). A very low radiation exposure may have the effect of hormesis, stimulating the hematopoietic function as expression in the immune system (Loken and Feinendegen, 1993; van Wyngarden and Pauwels, 1995; Luckey, 1994). There may be a threshold to this stimulation. Within the threshold value, the hematopoietic function increased with increasing radiation exposure; the hormetic hematopoietic function decreased as radiation exposure is increased to greater than the threshold.

An identification of this hormetic effect may have no immediate interpretation, i.e. the mechanisms are unknown. Yet, it does not seem that the significant associations between blood cell counts and the surrogate estimation of exposure are due to chance alone, as $P$-values were less than 0.001. Although exposure measurements or blood measurements had co-variate associations with smoking, drinking or ages, it is unlikely that those living near the nuclear power plants were younger, smoked or drank more. In order to advance our understanding of the health consequence of low dose radiation exposure, this phenomenon deserves attention and additional investigation, including the effects of smoking.

\section{Acknowledgements}

This study was supported in part by the Department of Health, People's Republic of China and 
from The Power Development Foundation, Taipei, Taiwan.

\section{References}

Boggs SS, Boggs DR. Multipotent stem cells in vivo. In: Golde DW, editor. Hematopoiesis. New York: Churchill Livingstone, 1984:1-72.

Boice JD Jr., Lubin JH. Occupational and environmental radiation and cancer. Cancer Causes Control 1997;8:309-322.

Bond VP, Wielopolski L, Shani G. Current misinterpretations of the linear no-threshold hypothesis. Health Phys 1996; 70:877-882.

Caldwell GC, Kelley DB, Health CW, Zack M. Polycythemia vera among participants of a nuclear weapons test. JAMA 1984;252:662-664.

Casarett AP. Radiation biology. Englewood Cliffs, New Jersey: Prentice-Hall Inc, 1968:171-216.

Cole J, Arlett CF, Green MHL, Holdsworth D, Tawm EJ, Bridges BA. Mutant frequencies in workers at the Sellafield installation. Health Phys 1995;68:388-393.

Cusick J. Radiation-induced myelomatosis. NEJM 1981; 304:204-210.

Daglish J. Radiophobia and radiation protection. Atom 1988;383:14-17.

Davies S. Environmental radiation surveillance at a nuclear fuel reprocessing plant. Am J Pub Health 1968;58: 2251-2260.

Doll R, Evans HJ, Darby SC. Paternal exposure not to blame. Nature 1994;367:678-679.

Drottz-Sjöberg BM, Persson L. Public reaction to radiation: Fear, anxiety, or phobia? Health Phys 1993;64:223-231.

Drottz-Sjöberg BM, Sjöberg L. Risk perception and worries after the Chernobyl accident. J Environ Psychol 1990;10: 135-149.

Fish BR. The role of nuclear energy in the control of air pollution. Nucl Safet 1969;10:119-130.

Hendee WR. Radiation phobia as a culturally mediated reflex. Health Phys 1990;59:763-764.

Little JB. Cellular, molecular, and carcinogenic effects of radiation. Hematol Oncol Clin North Am 1993;7:337-372.

Little MP, Charles MW, Wakeford R. A review of the risks of leukemia in relation to parental pre-conception exposure to radiation. Health Phys 1995;68:299-310.
Liu SZ, Liu WH, Sun JB. Radiation hormoesis: its expression in the immune system. Health Phys 1987;52:579-584.

Loken MK, Feinendegen LE. Radiation hormesis - its emerging significance in medical practice. Invest Radiol 1993;28:446-450.

Luckey TD. Radiation hormesis in relation to radiation protection. Chinese Medical J 1994;107:615-623.

MacMahon B. Some recent issues in low-exposure radiation epidemiology. Environ Health Perspect 1989;81:131-135.

Mossman KL. The linear no-threshold debate: where do we go from here? Med Phys 1998;25:279-284.

Nordenberg D, Yip R, Binkin NJ. The effect of cigarette smoking on hemoglobin and anemia screening. JAMA 1990;264:1556-1559.

Seed TM, Meyers SM. Chronic radiation-induced alteration in hematopoietic repair during preclinical phases of aplastic anemia and myeloproliferative disease: assessing unscheduled DNA synthesis responses. Cancer Res 1993;53: 4518-4527.

Shapiro J. Radiation protection - a guide for scientists and physicians. Boston, MA: Harvard University Press, 1990:334-429.

Slovic P, Flynn J, Layman M. Perceived risk, trust, and the politics of nuclear waste. Science 1991;254:1603-1607.

Sorahan T, Roberts PJ. Childhood cancer and paternal exposure to ionizing radiation: preliminary findings from the Oxford survey of childhood cancers. Am J Ind Med 1993; 23:343-354.

Tanke HJ, van Vianen PH, Emiliani FMF, Neuteboom I, de Vogel N, Tates AD, de Bruijn EA, van Oosterom AT. Changes in erythropoiesis due to radiation or chemotherapy as studied by flow cytometric determination of peripheral blood reticulocytes. Histochemistry 1986;84:544-548.

van Wyngarden KE, Pauwels EK. Hormesis: are low doses of ionizing radiation harmful or beneficial? Europe J Nuclear Med 1995;22:481-486.

Webster EW. Hormesis and radiation protection. Invest Radial 1993;28:451-453.

Dr Lee is a Professor and Superintendent at the National Taiwan University Hospital.

Drs Sung and Lin are Professors at the National Taiwan University College of Public Health. 